\title{
Strategi Percepatan Penguasaan Teknologi dan Industri Pertahanan: Studi Kasus Korea Selatan
}

\author{
Y. H. Yogaswara ${ }^{1}$
}

\begin{abstract}
Abstrak: Permasalahan utama Indonesia dalam penguasaan teknologi dan industri pertahanan terletak pada lemahnya regulasi sistem akusisi pertahanan yang mengakomodir proses penyerapan teknologinya. Rendahnya kualifikasi dan keahlian peneliti dan perekayasa turut memperparah lambatnya penyerapan teknologi. Selama kedua permasalahan mendasar tersebut tidak diselesaikan, maka perkembangan teknologi dan industri pertahanan tidak akan membaik secara signifikan. Untuk itu diperlukan solusi yang fokus untuk langsung mengatasi kedua permasalahan tersebut. Dengan pendekatan studi kasus terhadap perkembangan teknologi dan industri pertahanan Korea Selatan yang hanya dalam waktu tiga dekade terakhir telah mampu menyamai perkembangan negara maju selama satu abad, karya tulis ini menyarankan tiga strategi untuk mengejar ketertinggalan Indonesia di bidang ini. Pertama adalah reformasi sistem dan prosedur akusisi pertahanan melalui pelaksana tunggal langsung di bawah Menteri Pertahanan. Reformasi tersebut secara organisasi diformalkan dalam Lembaga Akusisi Pertahanan yang membawahi Badan Litbang Teknologi Pertahanan dan Badan Penjamin Mutu Teknologi Pertahanan. Integrasi institusi litbang pertahanan di Kemhan dan seluruh litbang angkatan ke dalam Badan Litbang dan Badan Penjamin Mutu Teknologi Pertahanan adalah strategi kedua yang ditujukan untuk optimalisasi penyerapan teknologi serta menghasilkan produk litbang yang berkualitas dan sinergis. Strategi terakhir adalah peningkatan kualitas sumberdaya manusia Lembaga Akuisisi Pertahanan melalui proses rekrutmen yang transparan dan akuntabel; Penempatan personel yang sesuai kualifikasi dan keahlian yang dibutuhkan; Sistem dan lingkungan kerja yang produktif dan kondusif; Pendidikan dan pelatihan berkelanjutan; Penjaminan pakta integritas setiap personel yang terlibat; Serta pengawasan berbasis ombudsman. Kerjasama litbang dengan institusi litbang pertahanan di luar Kemhan dan TNI serta perguruan tinggi atau alih status personel dari lembaga tersebut ke dalam Lembaga Akuisisi Pertahanan dapat menjadi solusi taktis peningkatan kualitas sumberdaya manusia. Tiga strategi tersebut diyakini mampu mempercepat penguasaan teknologi dan industri pertahanan di Indonesia dan mengakhiri ketergantungan Indonesia terhadap alutsista impor.
\end{abstract}

Kata Kunci: akuisisi, teknologi, industri, pertahanan 


\section{Latar Belakang}

Pembinaan dan peningkatan kemampuan pertahanan negara tidak dapat dilepaskan dari penguasaan teknologi dan industri pertahanan sebagai inti dalam pemenuhan kebutuhan alat utama sistem senjata (alutsista) bagi Tentara Nasional Indonesia (TNI). Walaupun telah didukung regulasi serta kesempatan untuk modernisasi alutsista yang akhir-akhir initerbuka lebar, namun kapasitas kemampuan teknolgi dan industri pertahanan Indonesia tetap rendah.Pemerintah Indonesia masih menghadapi sejumlah hambatan yang belum terselesaikan, sehingga membutuhkan kebijakan pertahanan yang dirumuskan dengan baik dan koheren (RSIS Indonesia Programme, 2012).Perkembangan industri pertahanan nasional yang sehat, teknologi yang dinamis, serta kemampuan penyerapan yang maksimal membutuhkan kebijakan yang praktis, kokoh dan fleksibel.Salah satu poin penting adalah perlunya penguatan kapasitas penelitian dan pengembangan (litbang) pertahanan melalui ofset teknologi atau kolaborasi internasional (RSIS Indonesia Programme, 2013).

Beberapa negara industri baru di Asia pada tahun 1960-an sampai 1990-an yang dikenal sebagai Four Asian Tigers yaitu Hongkong, Singapura, Korea Selatan dan Taiwan dapat dijadikan cermin untuk perbaikan di Indonesia. Negara-negara tersebut dikenal juga sebagaiNewlyIndustrializing Countries (NIC) pertama yang mampu berkompetisi secara internasional pada beberapa dekade terakhir. Pencapaian NIC tersebut pada prinsipnya didapat dengan carafokus pada strategi penguasaan teknologi yang paling relevan dengan kebutuhan negara, pada aspek yang paling menguntungkan, kemudian mengasimilasi, adaptasi dan improvisasi teknologi-teknologi yang diimpor tersebut

1 Penulis adalah Perwira Pertama TNI Angkatan Udara. Saat ini menjalankan tugas belajar program Doktor bidang Flight Dynamics, Guidance and Control; Dept. of Aerospace Engineeringdi kampus Korea Advanced Institute of Science and Technology (KAIST) atas beasiswa LPDP RI. Sejak Februari 2014 tinggal di Daejeon, Korea Selatan bersama istri dan tiga anak laki-lakinya. Penulis dapat dihubungi melalui email yh.yogaswara@kaist.ac.kr.
(Thee, 2005).Dari keempat negara tersebut, Korea Selatan yang paling sesuai untuk dijadikan model dalam percepatan penguasaan teknologi dan industri pertahanan di Indonesia. Selain pencapaiannyayang luar biasa, Korea Selatan juga memiliki kerjasama pertahanan yang strategis dengan Indonesia untuk alutsista matra darat, laut, maupun udara (SIPRI, 2017).Dengan melakukan studi kasusproses penguasaan teknologi dan industri pertahanan yang diterapkan oleh Korea Selatan, karya tulis ini merekomendasikan tiga strategi yang sesuai untuk diaplikasikan di Indonesia dengan pendekatan yang lebih realistis dan taktis. Dengan demikian, Indonesia dapat mempercepat penguasaan teknologi dan industri pertahanan untuk meningkatkan harkat, martabat, wibawa dan kehormatan Indonesia di mata dunia.

\section{Identifikasi Masalah}

Penguasaan dan peningkatan kemampuan pertahanan negara melalui pembelian alutsista di Indonesia dengan program berbasis Transfer of Technology (ToT, selanjutnya disebut sebagai transfer teknologi) menjadi pimadona dalam beberapa tahun terakhir. Transfer teknologi sebagai pengalihan kemampuan dan teknik know-howteknologi modern dari negara maju ke negara berkembang, dimana umumnya di Indonesia dilaksanakan melalui skema Foreign Direct Investment (FDI), Technical Licensing Agreement (TLA)atau disebut juga Foreign Licensing (FL), dan Capital Goods Import (CGI) (Thee, 2005). Namun seluruh skema dalam program transfer teknologi inibelum mampu menambah pengetahuan, meningkatkan keterampilan, dan memperluas kemampuan untuk pengorganisasian dan pengelolaan sumberdaya manusia Indonesia secara efektif. Permasalahan utama kondisi ini disebabkan belum adanya regulasi skema transfer teknologi yang spesifik, sedangkan tuntutan penguasaan teknologi sangat tinggi. Pertentangan antara beberapa kebijakan, distribusi aturan pada beberapa lembaga, koordinasi yang tidak efektif serta persaingan antar lembaga memperburuk kemampuan Indonesia untuk menerima transfer teknologi(Thalib, 2014).

Permasalahan tersebut di atas teridentifikasi bermuara pada aspek lemahnya sistem akuisisi pertahanan, dimana 
pengadaan alutsista hanya untuk pemenuhan kebutuhan saja tanpa dijadikan kesempatan untuk penguasaan teknologinya. Kalaupun ada skema ofset, transfer teknologi, atau kerjasama internasional dalam pengadaan alutsista, aspek kedua, yaitu rendahnya kemampuan litbang pertahanan, memberikan dampak yang signifikan dalam gagalnya pengalihan pengetahuan, kemampuan, dan metodedalam penguasaan teknologi dan industri pertahanan di Indonesia. Selama kedua permasalahan mendasar tersebut tidak diselesaikan, maka perkembangan teknologi dan industri pertahanan tidak akan membaik secara signifikan, yang pada akhirnya Indonesia akan tetap bertumpu pada impor alutsista.

\section{Kontribusi}

Karya tulis ini diharapkan dapat berkontribusi untuk memberikan wawasan baru tentang proses penguasaan teknologi dan industri pertahanan di Korea Selatan serta mengambil pelajaranyang dapat diimplementasikan secara strategis di Indonesia. Selanjutnya, karya tulis ini juga diharapkan dapat menjadi bahan pertimbangan bagi para pejabat terkait dan pemangku kepentingan untuk menetapkan regulasi dan mengambil kebijakandalam penguasaan teknologi dan industri pertahanan nasional yang optimal, efektif, dan efisien.

\section{Penguasaan Teknologi Pertahanan di Korea Selatan}

\subsection{Tinjauan Umum}

Sejak terlepas dari Perang Korea pada akhir tahun 1950-an, Korea Selatan dalam keadaan terpuruk dengan sumberdaya alam yang miskin dan sumberdaya manusia berpendidikan rendah. Pada tahun 1962, Korea Selatan meluncurkan program First Five Year Economic Development Plan yang diantaranya fokus pada peningkatan taraf pendidikan dan penyerapan teknologi baru. Melalui kebijakan tersebut, 100\% warga Korea Selatan berhasil melaksanakan pendidikan dasar pada tahun 1970. Pemerintah juga memberikan beasiswa besar-besaran kepada warganya untuk mendapat pendidikan tinggi di kampuskampus terbaik dunia.

Berbeda dengan negara-negara berkembang yang bertumpu pada skema FDI dan FL untuk menyerap teknologi baru, Korea Selatan justru melakukannya dengan skema pinjaman luar negeri jangka panjang. Dana hasil pinjaman tersebut kemudian digunakan untuk membiayai investasi industri yang jenisnya ditentukan pemerintah. Investasi ini mendorong impor masif barang teknologi tinggi dengan skema CGI dan pembangunan industri strategis. Selanjutnya industri tersebut melakukan rekayasa balik (reverse engineering) untuk mendapatkan teknologi yang diperlukan dari barang-barang yang diimpor. Proses rekayasa balik ini melibatkan kerjasama sinergi antara industri, perguruan tinggi dan lembaga litbang.

Pendekatan ini memiliki dua peran penting di awal perkembangan Korea Selatan, yaitu membantu industri untuk menguasai teknologi baruserta menarik kembali peneliti dan perekayasa yang ada di luar Korea Selatan. Pada tahun 1980, Korea Selatan hanya memiliki 321 laboratorium litbang industri dengan 5.100 orang peneliti, dimana hanya 56 orang lulusan Ph.D. Duapuluh tujuh tahun kemudian berkembang menjadi 14.975 laboratorium dengan lebih dari 190.000 orang peneliti termasuk sekitar 10.000 orang lulusan Ph.D. Dengan demikian, perkembangan teknologi yang dicapai Korea Selatan selama tiga dekade melebihi pencapaian negara-negara industri di Amerika dan Eropa selama satu abad (Chung, 2009).

\subsection{Perkembangan Teknologi Pertahanan}

Perkembangan teknologi pertahanan Korea Selatan tidak kalah cepat dengan perkembangan teknologi yang lainnya. Dengan prinsip dan pendekatan yang sama, teknologi pertahanan Korea Selatan semakin maju dengan dimulainya program ofset pada tahun 1983. Melalui program ofset ini, Korea Selatan mampu melaksanakan ekspor produknya ke luar negeri, mendukung produksi teknologi pertahanan domestik, pelaksanaan pemeliharaan dan perbaikan mandiri, serta memfasilitasi transfer teknologi dari negara lain. Pemerintah Korea Selatan sangat mendukung proyek kerjasama internasional yang berfokus pada pengembangan teknologi dari negara maju berupa kolaborasi riset internasional, kerjasama teknologi dengan negara maju, dan kerjasama lainnya.Korea Selatan bekerjasama dengan 16 negara maju, dimana Amerika, Inggris, Jerman, Perancis dan Italia adalah lima besar negara yang 
terkait dengan program ofset (Lee \& Lee, 2013).

Pelaksanaan program ofset pertahanan Korea Selatan terdiri atas dua kategori, yaitu skema ekspor dan transfer teknologi.Skema ekspor sangat menguntungkan Korea Selatan dalam bentuk penyediaan lapangan pekerjaan dan membangun basis industri pertahanan. Sedangkan melalui skema transfer teknologi, Korea Selatan mendapatkan paket data teknologi, bantuan dan dukungan teknis, pendidikan dan pelatihan, technology know-how, dan lain sebagainya. Teknologi yang didapatkan melalui skema ini umumnya diserap melalui sektor tenaga manusia dan diaplikasikan melalui program riset, proses manufaktur, serta operasi dan pemeliharaan materiil pertahanan.Akhir-akhir ini Korea Selatan menitikberatkan program ofset pertahanannya pada skema transfer teknologi(Han \& Park, 2004).

Sejak tahun 1990-an Korea Selatan fokus pada pengembangan senjata mutakhir berteknologi tinggi yang menjadi state of the art. Untuk efektifitas penyerapan muatan teknologi tersebut, Korea Selatan mendirikan Agency for Defense Development (ADD) sebagai pemain kunci yang diprioritaskan sebagai penerima transfer teknologi dan pelatihan. Sedangkan industri pertahanan menduduki posisi kedua sebagai penerima transfer teknologi. Teknologi pesawat dan peluru kendali merupakan grup industri terbesar yang mencapai $60 \%$ dari total pencapaian program ofset pertahanan. Grup industri terbesar selanjutnya adalah komunikasi dan elektronik sebesar $11 \%$ dan kapal laut sebesar 10\%. Sedangkan senjata kaliber kecil dan artileri, amunisi dan bahan peledak, serta kendaraan militer merupakan grup industri terkecil masing-masing kurang dari 5\%(Han \& Park, 2004).

\subsection{Sistem Akuisisi Pertahanan}

Seluruh prestasi dan penguasaan teknologi pertahanan yang dicapai Korea Selatan tidak terlepas dari regulasi yang dinamis mengikuti perkembangan jaman. Untuk mereformasi kegiatan akuisisi pertahanan yang transparan dan terhindar dari korupsi, pada tanggal 1 Januari 2006, Korea Selatan mendirikan lembaga Defense Acquisition Program Administration (DAPA). Lembaga negara khusus yang berada di bawah Ministry of National Defense (MND) ini bertanggung jawab untuk meningkatkan kemampuan pertahanan, pengadaan kebutuhan materiil militer, dan promosi industri pertahanan (ROK Act Number 13593, 2016, Article33). Seluruh proses akuisisi pertahanan dari mulai materiil terbaru berbobot teknologi tinggi hingga penyediaan perlengkapan personel lapangan dilaksanakan oleh DAPA. Selain itu, DAPA juga bertugas untuk mengelola proyek peningkatan kemampuan pertahanan, menerbitkan regulasi industri pertahanan, regulasi ekspor-impor materiil pertahanan, formulasi anggaran, serta pelaksanaan riset, analisa, pengujian, dan evaluasi teknologi pertahanan untuk matra darat, laut, dan udara.Untuk menjalankan fungsinya ini, lembaga litbang pertahanan ADD diintegrasikan ke dalam DAPA.Lembaga penjamin mutu Defense Agency for Technology and Quality (DTaQ)dibentuk dan berada sejajar dengan ADD di bawah DAPA.

Proses akuisisi pertahanan untuk Angkatan Bersenjatadi Korea Selatan yang meliputi Republic of Korea (ROK) Army, Navy, Air Force; seluruhnya dikelola terpusat oleh DAPA. Prosedur akuisisi diawali dengan pengusulan kebutuhan materiil pertahanan yang diajukan oleh masing-masing kepala staf angkatan. Selanjutnya para kepala staf yang tergabung dalam Joint Chiefs of Staff(JCS) dan MND melakukan analisa bersama untuk finalisasi kebutuhan tersebut dengan mempertimbangkan tujuan strategis dalam operasi gabungan maupun efisiensi. Keterlibatan organisasi militer dalam akuisisi pertahanan hanya sampai pada tahap ini, karena selanjutnya kebutuhan materiil pertahanan tersebut dikelola oleh DAPA. Setelah DAPA berhasil mengadakan, materiil tersebut diserahkan kepada Angkatan Bersenjata untuk penggunaan, pemeliharaan, hingga penghapusan.

DAPA melaksanakan analisa awaluntuk perencanaan akuisisi, termasuk rencana anggaran untuk usulan kebutuhan yang diterimanya. Dari hasil analisa tersebut, DAPA dapat menentukan alternatif untuk usulan yang diterimanya pada dua solusi, yaitu pembelian atau litbang. Pembelian itu sendiri dapat berupa pengadaan lokal dari industri nasional, impor dari luar negeri, atau sewa. Sedangkan litbangdilaksanakan dengan semangat kemandirian yang didukung oleh personel dan lembaga yang kredibel hingga dihasilkan prototipe sebagai produk awal. Keterlibatan penuh DAPA hanya sampai pada tes dan evaluasi yang 
dilaksanakan ADD berdasarkan persyaratan teknis yang disusun $\mathrm{DTaQ}$ terhadap prototipe hasil litbang maupun materiil hasil pembelian. Setelah itu, DAPA berfungsi memberikan asistensi dalam alur produksi massal, pembelian massal, pengiriman pada pengguna, penggunaan operasional, pemeliharaan, hingga penghapusan material tersebut(ROK Act Number 14610, 2017; DAPA, 2017).

Untuk mempertahankan DAPA sebagai lembaga yang kredibel, efisien, dan profesional, beberapa regulasi diberlakukan terhadap personel yang mengawaki lembaga ini.Setiap posisi di DAPA memiliki persyaratan kualifikasi dan keahlian tertentu untuk mendukung fungsinya dalam melaksanakan perencanaan, penelitian, rekayasa, analisa, tes, evaluasi, dan lain sebagainya (ROK Act Number 14610, 2017, Article7). Kualifikasi dan keahlian tersebut utamanya dinyatakan melalui persyaratan pendidikan formal pascasarjana, kursus, publikasi ilmiah, riwayat pekerjaan dan persyaratan tambahan lainnya untuk menduduki posisi yang sesuai tingkatannya. DAPA dipimpin oleh pejabat sipil dan diawaki oleh personel sipil maupun militer yang sesuai dengan persyaratan di atas. Untuk meningkatkan performa personel, MND dan DAPA dapat memberikan hibah dan hadiah kepada personelnya yang berhasil meneliti dan mengembangkan material pertahanan yang unggul atau teknologi inti yang terhubung terhadap materiil tersebut (ROK Act Number 14610, 2017, Article40). Namun pada sisi lain, untuk meningkatkan transparansi serta mengantisipasi korupsi dan penyimpangan, MND dan DAPA mewajibkan setiap orang yang terlibat dalam kegiatan program akuisisi pertahanan untuk menyatakan pakta integritas. Pakta integritas tersebut berisi larangan untuk meminta, menjanjikan, memberi, dan menerima segala jenis yang bernilai dari orang yang terlibat dalam akuisisi. Personel DAPA dan yang terlibat dengan proyeknya juga dilarang untuk menyampaikan informasi terkait program akuisisi pertahanan kepada yang tidak berhak.Selain itu, DAPA juga mengoperasikan sistem ombudsman internal untuk melaksanakan investigasi jika terjadi hal-hal yang tidak sesuai untuk selanjutnya dikoreksi atau dilanjutkan penindakan(ROK Act Number 14610, 2017, Article6).

\subsection{Proses Litbang Pertahanan}

Sebagaimana dijelaskan sebelumnya bahwa untuk menyerap teknologi pertahanan secara efektif dan efisien, Korea Selatan memfokuskan transfer teknologi pada ADD dan industri pertahanan. ADD merupakan satu-satunya lembaga riset pertahanan di Korea Selatan dan telah menjelma menjadi lembaga riset pertahanan kelas dunia. ADD berkontribusi untuk menguatkan dan mencapai kemandirian pertahanan nasional dengan cara melaksanakan survey, penelitian, pengembangan, dan pengujian terhadap senjata, peralatan, dan perbekalan yang dibutuhkan untuk pertahanan nasional termasuk aspek sains dan teknologi yang terkandung di dalam materiil pertahanan tersebut (ROK Act Number 13238, 2015, Article1).

Proses litbang terhadap materiil pertahanan dilaksanakan dan dipimpin oleh ADD setelah disetujui dan disahkan oleh DAPA. Untuk melaksanakan fungsi litbang pertahanan, ADD dilengkapi dengan pusat litbang sistem senjata darat, sistem senjata maritim dan bawah air, sistem senjata udara dan peluru kendali, peperangan elektronik dan informasi, serta divisi litbang teknologi inti (core technology) yaitu teknologi mutakhir yang lazim digunakan pada mayoritas sistem senjata.Sedangkan untuk tes dan evaluasi material hasil litbang maupun uji penerimaan material hasil pembelian, ADD memiliki fasilitas uji yang komprehensifdan akuntabel untuk seluruh matra serta materi uji dan evaluasi materiil pertahanan(ADD, 2012a).

Sejajar dengan ADD, DTaQ melaksanakan perencanaan teknologi pertahanan, manajemen kualitas pertahanan, sertifikasi materiil pertahanan, intelijen teknologi pertahanan, serta promosi teknologi pertahanan (ROK Act Number 13238, 2015, Article32; DTaQ, 2015). Dengan fungsinya tersebut, DTaQ dan ADD berkoordinasi untuk menghasilkan material litbang yang sesuai dengan perencanaan dan spesifikasi teknis dari DTaQ. Adapun dengan Angkatan Bersenjata, ADD berkoordinasi dalam konfirmasi persyaratan yang diusulkan satuan terkait. Pada kondisi tertentu, ADD berhak untuk menggunakan fasilitas dan perbekalan di satuan Angkatan Bersenjata apabila diperlukan untuk melaksanakan tugasnya (ROK Act Number 13238, 2015, Article21). ADD juga dapat melaksanakan proyek litbang bersama-sama dengan industri, perguruan tinggi, maupun lembaga litbang lainnya. Industri dapat terlibat dalam 
manufaktur prototipe maupun produksi massal. Sedangan perguruan tinggi dan lembaga litbang dapat terlibat dalam litbang dasar maupun aplikasi teknologi inti (ADD, 2012b). Dalam kaitannya kerjasama litbang, ADD tetap berdiri sebagai pimpinan proyek. Adapun kepemilikan hak kekayaan intelektual (HAKI) dari hasil litbang harus dimiliki oleh negara dan ADD, atau dimiliki bersama dengan lembaga terkait melalui perjanjian. DAPA dan ADD dapat memberikan lisensi HAKI yang dimilikinya kepada lembaga riset untuk dikembangkan ataukepada industri pertahanan untuk produksi massal(ROK Act Number 14610, 2017, Article31-2).

\section{Strategi Percepatan Penguasaan Teknologi dan Industri Pertahanan di Indonesia}

Ditinjau dari payung hukum, Pemerintah c.q. Kementerian Pertahanan RI (Kemhan) merupakan lembaga yang bertanggung jawab dalam pembinaan teknologi dan industri pertahanan (UUNo. 3 Tahun 2002, Pasal 16 (6), Pasal 20 (2), Pasal 23;UUNo. 34 Tahun 2004, Penjelasan Pasal 3(2);UUNo. 16 Tahun 2012). Regulasi penguasaan teknologi dan industri pertahanan melalui transfer teknologi dan ofset telah diatur pula secara umum melalui Kebijakan Umum Pertahanan Negara Tahun 2015-2019 (PerpresNo. 97 Tahun 2015). Dengan landasan tersebut dan dihubungkan dengan perkembangan teknologi dan industri pertahanan saat ini, Kemhan memiliki posisi kuat untuk memberikan solusiyang fokus terhadap permasalahan yang ada. Secara umum, solusi yang diperlukan adalah memperkuat sistem akuisisi pertahanan dan meningatkan kemampuan litbang pertahanan. Berkaca dari studi kasus Korea Selatan,karya tulis ini menyarankan tiga strategi untuk mengejar ketertinggalanIndonesia dalam penguasaan teknologi dan industri pertahanan.

dan Strategi pertama adalah reformasi sistem pertahananmelaluipelaksana tunggal pengadaan materiil pertahanan langsung dibawah Menteri Pertahanan. Pelaksana tunggal berupa Lembaga Akuisisi Pertahanan (LAP) inidapat mensinergikan seluruh sumberdaya secara optimal, efektif dan efisien dalam proses pengadaan alutsista untuk mendukung rencana strategis Kemhan dan TNI. Ide besar dalam strategi ini adalah memposisikan TNI sebagai tentara yang profesional dengan cara mengurangi keterlibatan TNI dalam proses pengadaan alutsista sehingga dapat fokus untuk berlatih dan mengembangkan kemampuan operasionalnya. Sebagaimana diilustrasikan pada Gambar 1, melalui sistem dan prosedur yang baru, keterlibatan TNI dalam proses akuisisi berada pada tahap pengusulan kebutuhan setiap matra melalui masingmasing Kepala Staf Angkatan. Selanjutnya Menteri Pertahanan, Panglima TNI, dan Kepala Staf Angkatan mengevaluasi dan memutuskan kebutuhan alutsista dengan mengacu pada analisa kebutuhan dan rencana strategis pertahanan. Proses pengadaan selanjutnya dilaksanakan oleh LAP melalui program pembelian maupun litbang. Program pembelian dilaksanakan berbasis industri domestik maupun impor dengan skema transfer teknologi, dimana keduanya sama-sama berperan dalam menyerap teknologi baru. Adapun program litbang dilaksanakan LAP hingga menghasilkan prototipe yang sesuai dengan persyaratan teknis yang telah dirumuskan dalam perencanaan akuisisi.Produksi massal dapat dilaksanakan oleh industri yang terlibat dalam program litbang atau melalui tender terbuka. Selanjutnya materiil pertahanan yang telah lulus uji dan evaluasi oleh LAP akan diserahterimakan kepada satuan TNI yang mengusulkannya. Strategi ini merupakan bagian yang paling menantang karena selain membutuhkan koordinasi dan sinergi antar pemangku kepentingan, namun juga secara teknis berhubungan langsung dengan perubahan regulasi pelaksanaan pengadaan alutsista bersama regulasi turunannya(Permenhan No. 17 Tahun 2014). Hambatan non teknis dalam mempertahankan status quo sistem akuisisi tidak kalah menantang, sehingga diperlukan kemauan politik yang kuat dari Kemhan sebagai regulator, para pemangku kepentingan, dan pihak terkait lainnya.

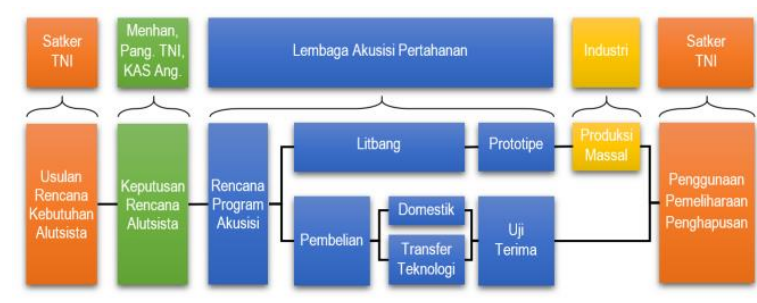

Gambar 1. Sistem dan Prosedur Akuisisi Pertahanan Indonesia 
Integrasi badan litbang pertahanan merupakan strategi kedua yang tidak kalah penting dan menantang untuk direalisasikan. Terpisahnya institusi litbang pertahanan di Kemhan dan tiap angkatan menyebabkan lemahnya proses penyerapan teknologi baru, tidak terkoordinasinya program litbang, hingga bermuara pada pemborosan anggaran dan sumberdaya. Integrasi seluruh institusi litbang pertahanan menjadi Badan Litbang Teknologi Pertahanan (Balitbang Tekhan) di bawah LAP menjadi organisasi seperti Gambar 2,adalah satu-satunya solusi untuk optimalisasi penyerapan teknologi serta menghasilkan produk litbang yang berkualitas dan sinergis. Balitbang Tekhan ini adalah pelaksana LAP dalam program litbang, transfer teknologi, hingga pendampingan teknis.Kelengkapan Balitbang Tekhan terdiri dari Pusat Litbang Teknologi Inti, Teknologi Matra Darat, Teknologi Matra Laut, Teknologi Matra Udara, serta Pusat Uji dan Evaluasi. Selain Balitbang, diperlukan juga distribusi sumberdaya dari institusi litbang lama ke Badan Penjamin Mutu Teknologi Pertahanan (BPM Tekhan) untuk fungsi perencanaan teknologi dan analisa kebutuhan berbasis rekayasa sistem, manajemen kualitas, sertifikasi materiil pertahanan, serta koordinasi litbang lintas institusi.Secara organisasi, struktur eselon dapat diterapkan sesuai dengan tugas, fungsi, dan wewenang setiap jabatan pada lembaga tersebut.

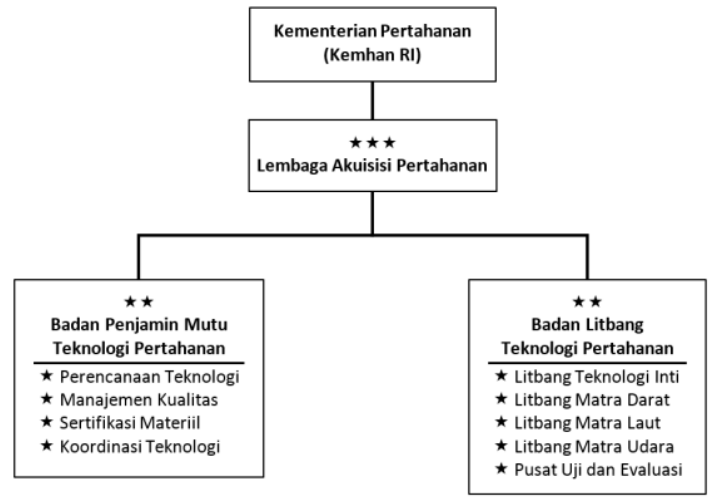

Gambar 2. Organisasi Lembaga Akuisisi Pertahanan Indonesia

Harus diakui bahwa rendahnya kualifikasi dan keahlian peneliti di setiap institusi litbang saat ini memperparah ketertinggalan teknologi dan industri pertahanan Indonesia. Untuk itu, strategi ketiga berkaitan dengan peningkatan kualitas sumberdaya manusia yang mengawaki LAP, khususnya fungsi peneliti, perekayasa, analis, dan penjamin mutu. Untuk mendapatkan personel yang sesuai dengan fungsi bidang tugasnya, diperlukan regulasi yang jelas dalam rekrutmen melalui persyaratan kualifikasi dan keahlian yang sesuai. Sebagai contoh, kualifikasi peneliti secara formal didapatkan melalui pendidikan doktoral dari perguruan tinggi yang diakui secara resmi oleh pemerintah (UU No. 12 Tahun 2012, Pasal 20).Persyaratan kualifikasi dan keahlian lainnya dapat disesuaikan dengan fungsi bidang tugasnya. Sedangkan untuk meningkatkan produktivitas, perlu dibuat regulasi dimana personel LAP dapat fokus melaksanakan fungsi peneliti, perekayasa, analis, penjamin mutu, dan fungsi teknis lainnya, tanpa beban pertanggungjawaban administrasi yang berlebihan. Pada sisi lain, untuk meningkatkan akuntabilitas dan antisipasi penyalahgunaan wewenang, setiap personel LAP diwajibkan mengisi dan menandatangani pakta integritas. Selain itu, sistem pelaporan berbasis ombudsman dapat diterapkan untuk pengawasan prosedur yang lebih ketat.

Solusi taktis pengawakan LAP yang berkualitas adalah dengan melaksanakan kerjasama program litbang dengan beberapa lembaga pemerintah di luar Kemhan dan TNI yang terkait dengan teknologi pertahanan maupun alih status personel dari lembaga tersebut ke dalam LAP. Lembaga yang dimaksud tersebut diantaranya adalah Pusat Teknologi Industri Pertahanan dan Keamanan, Badan Pengkajian dan Penerapan Teknologi (PTIPK BPPT, 2017); Pusat Teknologi Pertahanan dan Keamanan, Institut Teknologi Bandung (Pustekhankam ITB, 2017); serta Fakultas Teknologi Pertahanan, Universitas Pertahanan (Unhan, 2016). Adapun pengawakan personel sipil dan militer di LAP dapat disesuaikan dengan kebutuhan berbasis program, kualifikasi, dan keahlian yang dibutuhkan.Selanjutnya, pendidikan dan pelatihan yang terkait dengan fungsi dan tugas pokoknya dilaksanakan secara bertahap dan berkelanjutan.

\section{Kesimpulan}

Permasalahan utama Indonesia dalam penguasaan teknologi dan industri pertahanan mengerucut pada lemahnya regulasi sistem akusisi pertahanan untuk mengakomodir proses penyerapan teknologi. Permasalahan lainnya adalah kualifikasi dan keahlian peneliti dan perekayasa yang rendah sehingga memperparah lambatnya penyerapan teknologi pertahanan. Selama kedua permasalahan mendasar tersebut 
tidak diselesaikan, maka perkembangan teknologi dan industri pertahanan tidak akan membaik secara signifikan, yang pada akhirnya Indonesia akan tetap bertumpu pada impor alutsista. Untuk itu diperlukan solusi yang fokus untuk langsung mengatasikedua permasalahan tersebut.

Perkembangan Korea Selatan hanya dalam waktu tiga dekade terakhir telah mampu menyamai perkembangan negara maju selama satu abad. Studi kasus penguasaan teknologi dan industri pertahanan Korea Selatan dapat menjadi solusi untuk mengejar ketertinggalan Indonesia di bidang ini. Berkaca dari Korea Selatan, tiga strategi yang sesuai dengan kondisi Indonesia diusulkan dalam karya tulis ini untuk mengatasi permasalahan yang telah teridentifikasi di atas. Strategi pertamaadalah reformasi sistem dan prosedur akusisi pertahanan melalui pelaksana tunggal langsung di bawah Menteri Pertahanan.Reformasi tersebut secara organisasi diformalkan dalam Lembaga Akusisi Pertahanan yang membawahi Badan Litbang Teknologi Pertahanan dan Badan Penjamin Mutu Teknologi Pertahanan. Integrasi institusi litbang pertahanan di Kemhan dan seluruh litbang angkatan ke dalam Badan Litbang dan Badan Penjamin Mutu Teknologi Pertahanan adalah strategi kedua yang ditujukan untuk optimalisasi penyerapan teknologi serta menghasilkan produk litbang yang berkualitas dan sinergis. Strategi terakhir adalah peningkatan kualitas sumberdaya manusia Lembaga Akuisisi Pertahanan melalui proses rekrutmen yang transparan dan akuntabel;Penempatan personel yang sesuai kualifikasi dan keahlian yang dibutuhkan; Sistem dan lingkungan kerja yang produktif dan kondusif; Pendidikan dan pelatihan berkelanjutan; Penjaminan pakta integritas setiap personel yang terlibat; Serta pengawasan berbasis ombudsman. Kerjasama litbang dengan institusi litbang pertahanan dan perguruan tinggi atau alih status personel tersebut ke dalam Lembaga Akuisisi Pertahanan dapat menjadi solusi taktis peningkatan kualitas sumberdaya manusia.Tiga strategi tersebut diyakini mampu mempercepat penguasaan teknologi dan industri pertahanan di Indonesia dan mengakhiri ketergantungan terhadap alutsista impor.

\section{Persantunan}

Penulis menyampaikan ucapan terima kasih dan penghargaan kepada Panglima TNI dan Kepala Staf TNI Angkatan Udara atas izin tugas belajar dan bantuannya; serta kepada Lembaga Pengelola Dana Pendidikan RI (LPDP RI) sebagai pemberi beasiswa pendidikan. Atas dukungannya, Penulis dapat melaksanakan pendidikan Program Doktor bidang Aerospace Engineering di Korea Advanced Institute of Science and Technology (KAIST), Korea Selatan; mengikuti Guided Weapon Course di The Defence Academy of the United Kingdom;serta penelitian di Centre for Autonomous and Cyberphysical Systems, Cranfield University, Inggris.

\section{Kepustakaan}

Agency for Defence Development (ADD), 2012a. Test and Evaluation. Available at: http://add.re.kr/ [Accessed September 28, 2017].

Agency for Defence Development (ADD), 2012b. Weapon System and Technology. Available at: http://add.re.kr/ [Accessed September 28, 2017].

Chung, S., 2009. Innovation, Competitiveness and Growth: Korean Experiences. In The Annual Bank Conference on Development Economics (ABCDE) by The World Bank and the Government of Republic of Korea. Seoul, pp. 1-29.

Defense Acquisition Program Administrator (DAPA), 2017. Weapon System Acquisition. Available at: http://www.dapa.go.kr/mbshome/mbs/da pa_eng/subview.jsp?id=dapa_eng_0301 00000000 [Accessed September 28, 2017].

Defense Agency for Technology and Quality (DTaQ), 2015. What We Do. Available at: http://www.dtaq.re.kr/en/work/analysis.js p [Accessed September 28, 2017].

Han, N.S. \& Park, J.S., 2004. The Defense Offset Policy in South Korea. The Korea Institute for Defense Analyses Papers, 4.

Lee, H. \& Lee, J., 2013. Korean Offset Trade Model in Defense Industry. Advanced Science and Technology Letters, 34(Business 2013), pp.58-61.

Peraturan Menteri Pertahanan RI Nomor 17 Tahun 2014, 2014. Pelaksanaan Pengadaan Alat Utama Sistem Senjata di Lingkungan Kementerian Pertahanan dan Tentara Nasional Indonesia, 
Peraturan Presiden RI Nomor 97 Tahun 2015, 2015. Kebijakan Umum Pertahanan Negara Tahun 2015-2019, Jakarta: Lembaran NegaraRepublik Indonesia Tahun 2015 Nomor 200.

PTIPK BPPT, 2017. Pusat Teknologi Industri Pertahanan dan Keamanan (PTIPK). Available at: http://ptipk.bppt.go.id/ [Accessed September 28, 2017].

Pustekhankam ITB, 2017. Pusat Teknologi Pertahanan dan Keamanan - Institut Teknologi Bandung (Pustekhankam ITB). Available at: https://pustekhan.itb.ac.id/tentang-kami/ [Accessed September 27, 2017].

Republic of Korea Act Number 13238, 2015. Act on The Agency for Defense Development, Seoul: Ministry of Government Legislation.

Republic of Korea Act Number 13593, 2016. Government Organization Act, Seoul: Ministry of Government Legislation.

Republic of Korea Act Number 14610, 2017. Defense Acquisition Program Act, Seoul: Ministry of Government Legislation.

RSIS Indonesia Programme, 2013. Indonesia 's Emerging Defence Economy: The Defence Industry Law and Its Implications, Nanyang: S. Rajaratnam School of International Studies.

RSIS Indonesia Programme, 2012. Revitalizing Indonesia's Defence Industrial Base: Agenda for Future Action, Nanyang: S. Rajaratnam School of International Studies.

Stockholm International Peace Research Institute (SIPRI), 2017. Transfers of
Major Weapons of South Korea to Indonesia: Deals with Deliveries or Orders Made for 2005 to 2016. Trade Registers. Available at: http://armstrade.sipri.org/armstrade/pag e/trade_register.php September 25, 2017].

[Accessed

Thalib, A., 2014. Technology Transfer in Indonesia: Legal Perspective. UUM Journal of Legal Studies, 5(14), pp.7592.

Thee, K.W., 2005. The Major Channels of International Technology Transfer to Indonesia: An Assessment. Journal of the Asia Pacific Economy, 10(2), pp.214-236.

Undang-Undang RI Nomor 12 Tahun 2012, 2012. Pendidikan Tinggi, Jakarta: Lembaran Negara Republik Indonesia Tahun 2012 Nomor 158.

Undang-Undang RI Nomor 16 Tahun 2012, 2012. Industri Pertahanan, Jakarta: Lembaran Negara Republik Indonesia Tahun 2012 Nomor 183.

Undang-Undang RI Nomor 34 Tahun 2004, 2004. Tentara Nasional Indonesia, Jakarta: Lembaran Negara Republik Indonesia Tahun 2004 Nomor 127.

Undang-Undang RI Nomor 3 Tahun 2002, 2002. Pertahanan Negara, Jakarta: Lembaran Negara Republik Indonesia Tahun 2002 Nomor 3.

Universitas Pertahanan, 2016. Fakultas Teknologi Pertahanan. Available at: http://www.idu.ac.id/fakultas/fakultasteknologi-pertahanan/

September

27,

[Accessed 2017]. 